Article

\title{
Cr Segregation and Impact Fracture in a Martensitic Stainless Steel
}

\author{
Eleonora Bolli ${ }^{1,2, *}$, Alessandra Fava ${ }^{3}$, Paolo Ferro ${ }^{4}\left(\mathbb{D}\right.$, Saulius Kaciulis ${ }^{2}$ (D), Alessio Mezzi ${ }^{2}$, \\ Roberto Montanari ${ }^{1}$ (D) and Alessandra Varone ${ }^{1, *}$ \\ 1 Department of Industrial Engineering, University of Rome “Tor Vergata”, Via del Politecnico 1, \\ 00133 Rome, Italy; roberto.montanari@uniroma2.it \\ 2 Institute for the Study of Nanostructured Materials, ISMN - CNR, Monterotondo Stazione, \\ 00015 Rome, Italy; Saulius.kaciulis@cnr.it (S.K.); alessio.mezzi@cnr.it (A.M.) \\ 3 Department of Energy, Nuclear Engineering Division, Politecnico di Milano, Piazza L. da Vinci 32, \\ 20133 Milan, Italy; alessandra.fava@uniroma2.it \\ 4 Department of Engineering and Management, University of Padova, Stradella San Nicola 3, \\ 36100 Vicenza, Italy; paolo.ferro@unipd.it \\ * Correspondence: eleonora.bolli@ismn.cnr.it (E.B.); alessandra.varone@uniroma2.it (A.V.); \\ Tel.: +39-06-90672892 (E.B.); +39-06-72597180 (A.V.)
}

Received: 4 August 2020; Accepted: 27 August 2020; Published: 29 August 2020

\begin{abstract}
The fracture surfaces of a $10.5 \mathrm{wt} . \% \mathrm{Cr}$ martensitic stainless steel broken in Charpy tests have been investigated through X-ray photoelectron spectroscopy (XPS). The specimens have been examined in two different conditions: as-quenched and heat treated for $10 \mathrm{~h}$ at $700{ }^{\circ} \mathrm{C}$. The trends of $\mathrm{Fe} / \mathrm{Cr}$ ratio vs. test temperature are similar to the sigmoidal curves of absorbed energy and, after both ductile and quasi-cleavage brittle fractures, such ratio is always significantly lower than the nominal value of the steel chemical composition. Cr segregation does not occur on a macroscopic scale but takes place in microscopic zones which represent weaker spots in the steel matrix and a preferred path for moving cracks. Small area (diameter $300 \mu \mathrm{m}$ ) XPS measurements evidenced a higher density of such microscopic zones in the inner part of probes; this is explained by the different diffusion length of $\mathrm{Cr}$ atoms in the external and inner parts during quenching from austenitic field which has been calculated through FEM simulations. No significant differences of $\mathrm{Cr}$ concentration were observed in fracture surfaces of probes with and without heat treatment. The results highlight how $\mathrm{Cr}$ segregation plays a role not only in the intergranular mode of fracture but also in the quasi-cleavage and ductile ones.
\end{abstract}

Keywords: martensitic stainless steel; Cr segregation; fracture; Charpy test; XPS

\section{Introduction}

Since the eighties, $\mathrm{Cr}$ martensitic steels with controlled impurity contents have drawn the attention of engineers and materials scientists for replacing austenitic stainless steels in structural applications in future nuclear fusion reactors [1-3]. Reduced activation martensitic steels (RAMS) have been developed by substituting alloying elements such as $\mathrm{Mo}, \mathrm{Nb}, \mathrm{Ni}$, and $\mathrm{Co}$, which cause long-lived transmutation nuclides, with other elements, e.g., $\mathrm{W}$, Ta, and V, leading to relatively short-lived transmutation nuclides. A review of the work done from early stages of RAMS to their more recent qualification for reactor design codes is reported in [4]. A lot of research has been devoted to investigating topics such as activation, swelling, embrittlement, and creep resistance because the microstructural and mechanical stability at high temperature and under neutron irradiation is of utmost importance for this application. 
The influence of austenitization temperature on martensitic transformation $[5,6]$ and the effects of tempering on texture evolution [7], micro-strains [8,9], and ductile to brittle transition temperature (DBTT) [10] have been carefully studied by examining different RAMS. One of the critical issues in the use of the martensitic steels is the embrittlement induced by heat treatments because martensite decomposes into a Cr-rich $\alpha^{\prime}$ and a Cr-poor $\alpha$ phase with consequent progressive hardening and deterioration of fracture toughness [11]. Such phenomenon depends on the $\mathrm{Cr}$ content of the alloy and strengthening increases with the size of $\alpha^{\prime}$ zones [12].

Since $\mathrm{Cr}$ segregation affects many physical phenomena occurring in $\mathrm{Fe}-\mathrm{Cr}$ or $\mathrm{Fe}-\mathrm{Cr}-\mathrm{C}$ alloys which have different industrial applications, the physical mechanisms and precursor stages are extensively studied. Li et al. [13] investigated by means of atom probe tomography (APT) the C-Cr co-segregation at grain boundaries and found a concentration periodicity of $\sim 7 \mathrm{~nm}$. Through a cross-correlative precession electron diffraction-atom probe tomography investigation the $\mathrm{Cr}$ segregation in a $\mathrm{Fe}(\mathrm{Cr})$ nanocrystalline alloy was found to be dependent on grain boundary type [14]. Segregation, precipitation, and phase separation in Fe-Cr systems have been analyzed by Kuronen et al. [15], showing that the precipitation of $\mathrm{Cr}$ occurs into isolated pockets in bulk $\mathrm{Fe}-\mathrm{Cr}$ alloys with $\mathrm{Cr}$ content higher than 10 at.\%. Mirebeau et al. [16] and Dubiel et al. [17-20] evidenced that short range order (SRO) develops in Fe-Cr alloys following prolonged heat treatments up to $\sim 630{ }^{\circ} \mathrm{C}$ with a clustering tendency. To explain the corrosion behavior of Fe-Cr alloys Liu et al. [21] considered the effect of SRO on establishing a percolation network of $\mathrm{Cr}$ atoms.

A relevant finding of Mechanical Spectroscopy (MS) investigations on $\mathrm{Cr}$ martensitic steels is the presence of $\mathrm{C}-\mathrm{Cr}$ associates and clusters in as-quenched martensite [22]. Small-angle neutron scattering (SANS) measurements showed that their size is $<5 \mathrm{~nm}$ [6]. The C-Cr associate distribution changes with quenching rate from austenitic field and evolves following heat treatments, leading in some cases to contiguous $\mathrm{Cr}$-rich and $\mathrm{Cr}$-poor zones, which affect both radiation resistance and fracture behaviour [23-25]. Recently, an analytic study of such point defect structures (C-Cr associates) and of their role on $\mathrm{Cr}$ segregation has been carried out through MS experiments [26].

Remarkable differences in fracture mode and DBTT have been observed in samples quenched from austenitic field with slow $\left(150^{\circ} \mathrm{C} / \mathrm{min}\right)$ and fast $\left(3600^{\circ} \mathrm{C} / \mathrm{min}\right)$ cooling rates, and successively heat treated at $700{ }^{\circ} \mathrm{C}$ for increasing time. The samples cooled with the slower rate exhibit a mixed mode of brittle fracture (quasi-cleavage plus inter-crystalline) whereas quasi-cleavage fracture is observed in samples cooled with the faster one. This was explained by the $\mathrm{Cr}$ enrichment at grain boundaries occurring in slowly cooled samples and favoured by the specific distribution of $\mathrm{C}$-Cr associates after quenching [27]. This represents an important achievement for better understanding the physical mechanisms governing the embrittlement of $\mathrm{Cr}$ martensitic steels, however there are some still open problems. Firstly, it is necessary to assess whether $\mathrm{Cr}$ segregation, even to a minor extent, occurs also in samples cooled with fast rate. The second problem is to clarify its role in the process of fracture in both ductile and brittle fields.

Moreover, recent X-ray photoelectron spectroscopy (XPS) analyses carried out on the fracture surfaces evidenced the segregation of $\mathrm{Cr}$ in both ductile and brittle (quasi-cleavage) fields [28]. To shed more light on these aspects, the fracture behaviour of a $\mathrm{Cr}$ martensitic steel prepared in two different conditions, (1) as-quenched with cooling rate of $3600{ }^{\circ} \mathrm{C} / \mathrm{min}$ and (2) quenched and annealed at $700{ }^{\circ} \mathrm{C}$ for $10 \mathrm{~h}$, has been investigated through Charpy tests. Then, XPS measurements have been carried out on the fracture surfaces of probes broken in ductile and brittle field to assess possible variations of $\mathrm{Cr}$ content with respect to the mean value of the alloy.

\section{Materials and Methods}

The nominal composition of the examined martensitic stainless steel is reported in Table 1. 
Table 1. Chemical composition of the investigated Cr martensitic steel (wt.\%).

\begin{tabular}{cccccccccccc}
\hline $\mathbf{C}$ & $\mathbf{C r}$ & $\mathbf{M o}$ & $\mathbf{N i}$ & $\mathbf{M n}$ & $\mathbf{N b}$ & $\mathbf{V}$ & $\mathbf{S i}$ & $\mathbf{A l}$ & $\mathbf{N}$ & $\mathbf{P}$ & $\mathbf{F e}$ \\
\hline 0.17 & 10.50 & 0.50 & 0.85 & 0.60 & 0.20 & 0.25 & 0.32 & 0.05 & 0.003 & 0.005 & to balance \\
\hline
\end{tabular}

According to ASTM A370, standard V-notched probes $\left(55 \times 10 \times 10 \mathrm{~mm}^{3}\right)$ for Charpy tests were manufactured from a $10 \mathrm{~mm}$-thick plate. They were treated for $30 \mathrm{~min}$ at $1075^{\circ} \mathrm{C}$ (austenitic field) then quenched with a cooling rate of $3600{ }^{\circ} \mathrm{C} / \mathrm{min}$, measured by a thermocouple put in direct contact with the probe surface. A set of probes were tested in as-quenched condition while another set was heated for $10 \mathrm{~h}$ at $700{ }^{\circ} \mathrm{C}$.

The Charpy tests were performed according to the UNI EN ISO 148-1:2016 [29] standard in the temperature range from -100 to $+150^{\circ} \mathrm{C}$. The image of a broken probe is displayed in Figure 1 while the absorbed energy vs. test temperature is shown in Figure 2. Each point in the graph is the mean value of five tests and the error bars represent the standard deviation. After fitting experimental data through sigmoidal curves DBTT was determined as the temperature corresponding to (USE + LSE)/2, where USE and LSE are the upper and lower shelf energies, respectively. Table 2 reports the values of DBTT and USE determined from the curves in Figure 2. After the heat treatment DBTT shifts towards lower temperatures, the change is $\sim 40^{\circ} \mathrm{C}$.

Table 2. Ductile to brittle transition temperature (DBTT) and USE values determined from the curves in Figure 2.

\begin{tabular}{ccc}
\hline Heat Treatment & DBTT $\left({ }^{\circ} \mathbf{C}\right)$ & USE (J) \\
\hline As-quenched & +18 & 114 \\
$10 \mathrm{~h} / 700{ }^{\circ} \mathrm{C}$ & -18 & 142 \\
\hline
\end{tabular}

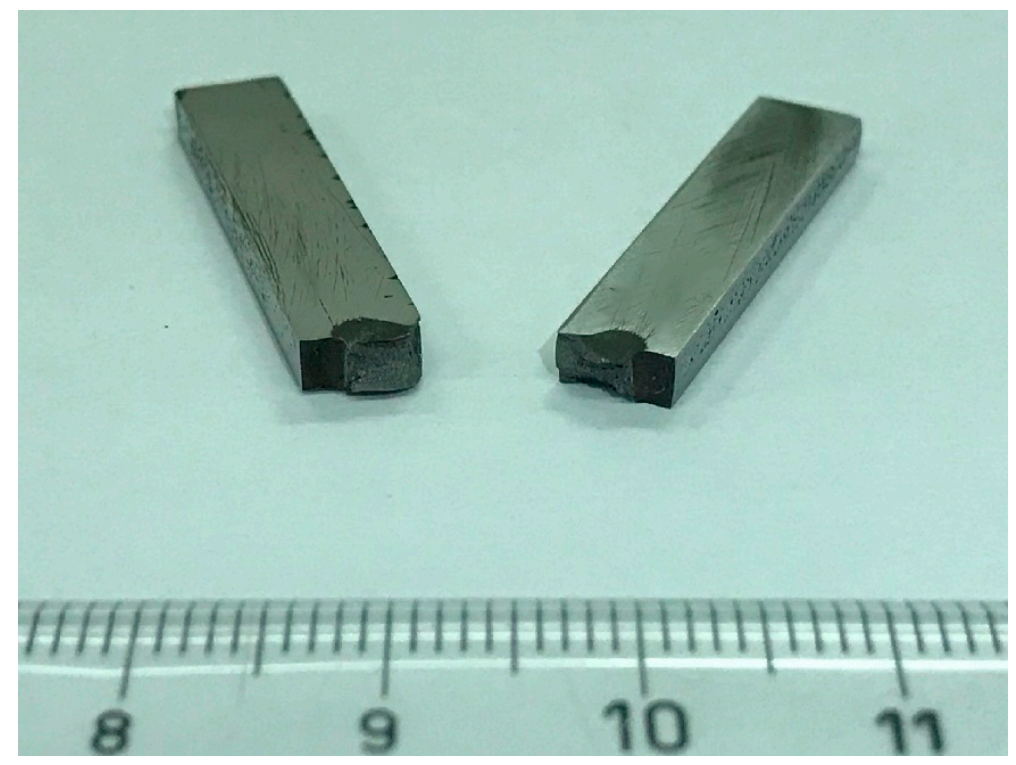

Figure 1. A probe broken in Charpy test (ductile field). 


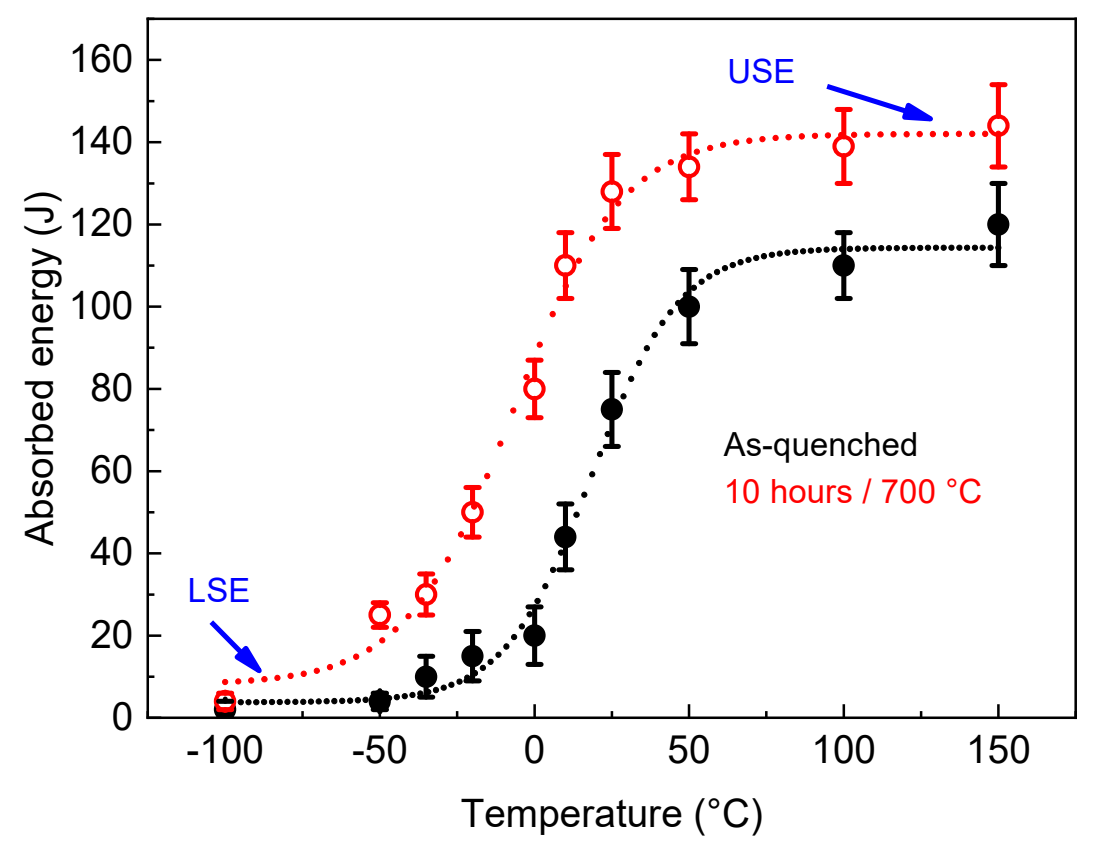

Figure 2. Absorbed energy vs. test temperature of $\mathrm{Cr}$ martensitic steel in as-quenched condition and after heat treatment for $10 \mathrm{~h}$ at $700{ }^{\circ} \mathrm{C}$.

The material structure after quenching and successive heat treatment has been investigated by scanning electron microscopy (SEM Hitachi SU70, Hitachi, Tokyo, Japan) and X-ray diffraction (XRD). XRD patterns of the most intense reflections have been collected (Philips, Eindhoven, The Netherlands) with the Mo-K $\alpha$ radiation $(\lambda=0.071 \mathrm{~nm})$ in step-scanning mode with $2 \theta$ steps of $0.005^{\circ}$ and counting time of $10 \mathrm{~s}$ per step. In order to determine the fracture mode and possible effects of Cr segregation, the surfaces of the probes broken at different temperatures were examined by SEM and EDS microanalysis (Thermo Scientific 4443F, Madison, WI, USA).

The XPS measurements were carried out on the fracture surfaces of the two sets of samples. Because of excessive $C$ contamination, before the analysis each sample was cleaned by the chemical etching at room temperature in a solution of $\mathrm{HCl}$ diluted to $12.3 \%$ for a duration of $30 \mathrm{~s}$. The acid was then removed by washing the specimens with ultra-pure water in ultrasonic bath. The XPS experiments were performed by using an Escalab 250 Xi (Thermo Fisher Scientific Ltd., East Grinstead, $\mathrm{UK})$ with a monochromatic Al X-ray source $(\mathrm{h} v=1486.6 \mathrm{eV})$ at a spot size of $900 \mu \mathrm{m}$. The spectrometer was equipped with a hemispherical analyser and 6-channeltrons as a detector. The fracture surface of every sample was investigated in ultra-high vacuum (UHV), keeping the base pressure in the analysis chamber of about $10^{-10}$ mbar. The pressure was increased, when the $\mathrm{Ar}^{+}$ion gun EX06 was turned on during the XPS depth profiling. The ion gun used for the $\mathrm{Ar}^{+}$sputtering was operated at energy of $2 \mathrm{keV}$ and beam current density of $2.5 \mathrm{~mA} \mathrm{~cm}^{-2}$. XPS regions were acquired at pass energy of $40 \mathrm{eV}$ and standard electromagnetic lens mode, corresponding to $\sim 1 \mathrm{~mm}$ in diameter of analyzed sample area. Moreover, multipoint analysis over the fracture surfaces was carried on in small-area lens mode, corresponding to $300 \mu \mathrm{m}$ in diameter. The binding energy $\mathrm{BE}=285.0 \mathrm{eV}$, corresponding to $\mathrm{C} 1 \mathrm{~s}$ peak of adventitious carbon, was used for the scale calibration. The spectra were acquired and processed by Avantage v.5 software, where the smart mode background subtraction was applied for quantitative analysis.

A numerical model was developed using Sysweld ${ }^{\circledR}$ code to investigate the thermal gradients within the sample during the imposed rapid cooling. Thermal properties were taken as a function of temperature and phases (Figure 3a). The austenitic to martensitic transformation was modelled using the well-known Koistinen-Marburger equation [30,31] with martensite start temperature set equal to $375^{\circ} \mathrm{C}$. The numerical model, shown in Figure 3b, consisted of 14,000 linear finite elements. 

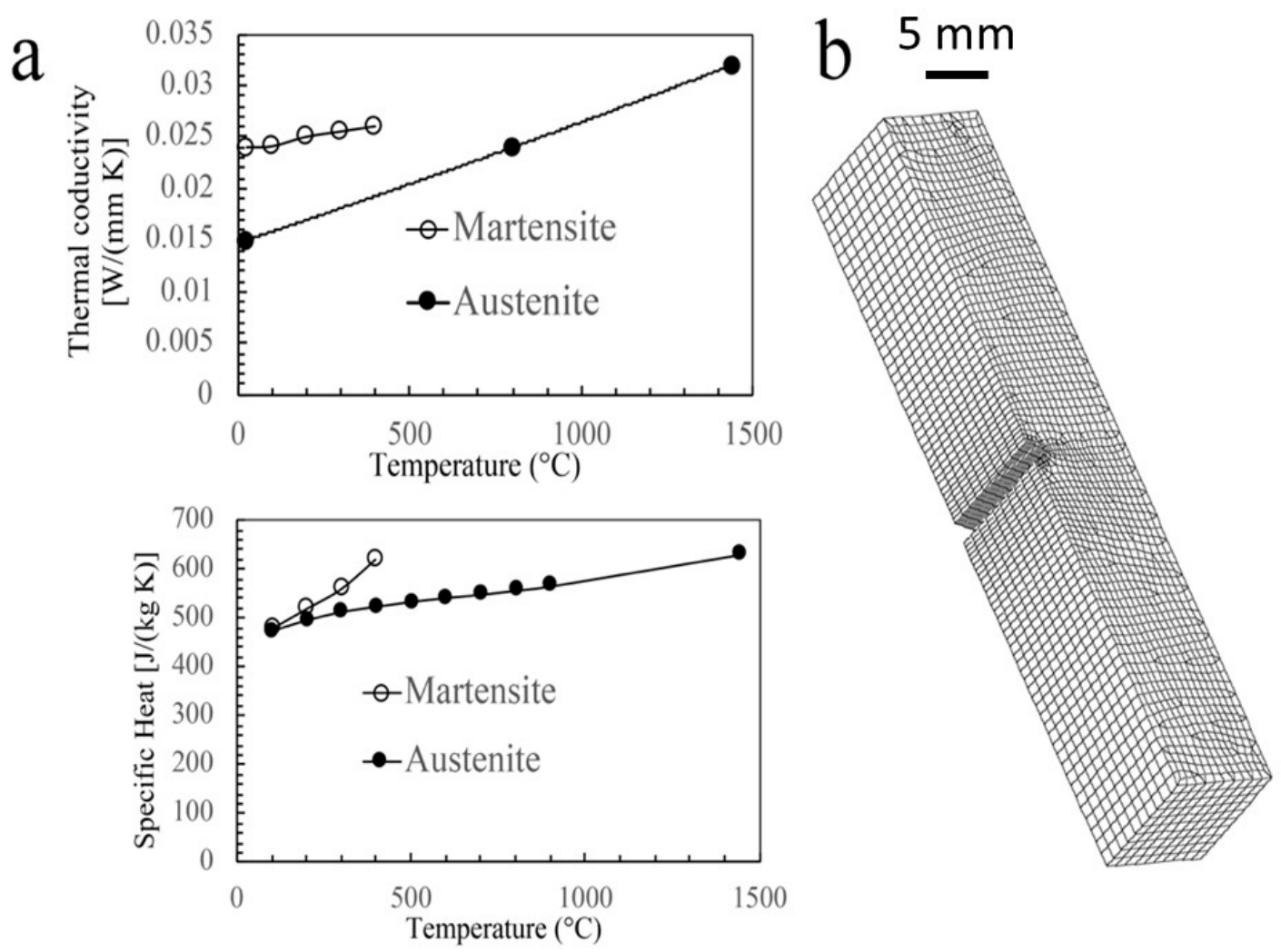

Figure 3. Thermal material properties of the steel investigated (a) and 3D numerical model used for the thermal analysis (b).

The temperature at nodes belonging to the external surface was made to vary from $1075{ }^{\circ} \mathrm{C}$ to room temperature with a constant cooling rate of $3600^{\circ} \mathrm{C} / \mathrm{min}$ (boundary condition).

\section{Results and Discussion}

It is well known that $C$ and impurities like $P$ are site competitors, thus the free $C$ atoms tend to suppress $\mathrm{P}$ segregation at grain boundaries and consequently intergranular embrittlement. Since $\mathrm{Cr}$ or other carbide-forming elements decrease the concentration of free $\mathrm{C}$ in the steel matrix, it is reasonable to expect high impurity grain boundary segregation in an alloy with $\mathrm{Cr}$ content $>11 \mathrm{wt} . \%$. In the examined steel, $\mathrm{P}$ content is very low $(0.005 \mathrm{wt} . \%)$ to avoid specific embrittlement; the P rich $\chi$-phase was found to nucleate during proton irradiation at pre-existing $\mathrm{NbC}$ precipitates [32], however $\mathrm{P}$ segregation after heat treatments at $700{ }^{\circ} \mathrm{C}$ is not reported in literature. Therefore, the attention of present work is focused on $\mathrm{Cr}$ segregation.

The microstructural evolution induced by heat treatments is displayed in Figure 4. After quenching, the steel is fully martensitic and exhibits a typical martensitic structure consisting of laths organized in packets; each prior austenitic grain (PAG) contains several packets. After the heat treatments, the laths disappear, $\mathrm{M}_{23} \mathrm{C}_{6}(\mathrm{M}=\mathrm{Cr}, \mathrm{Fe})$ carbides form decorating PAGs and the interfaces between previous laths. The mean chemical composition (wt. $\%$ ) of $\mathrm{M}_{23} \mathrm{C}_{6}$ carbides is $\mathrm{C} 6 \%, \mathrm{Cr} 65 \%$, and $\mathrm{Fe} 29 \%$. Since the carbide precipitation is substantially completed after $2 \mathrm{~h}$ at $700{ }^{\circ} \mathrm{C}$, no remarkable difference is observed between the samples treated for $10 \mathrm{~h}$. The $\mathrm{Cr}$ profiles in the images of Figure 4 do not show a specific trend but only fluctuations from point to point. Such Cr fluctuations are of the order of $7-8 \mathrm{wt} . \%$. 


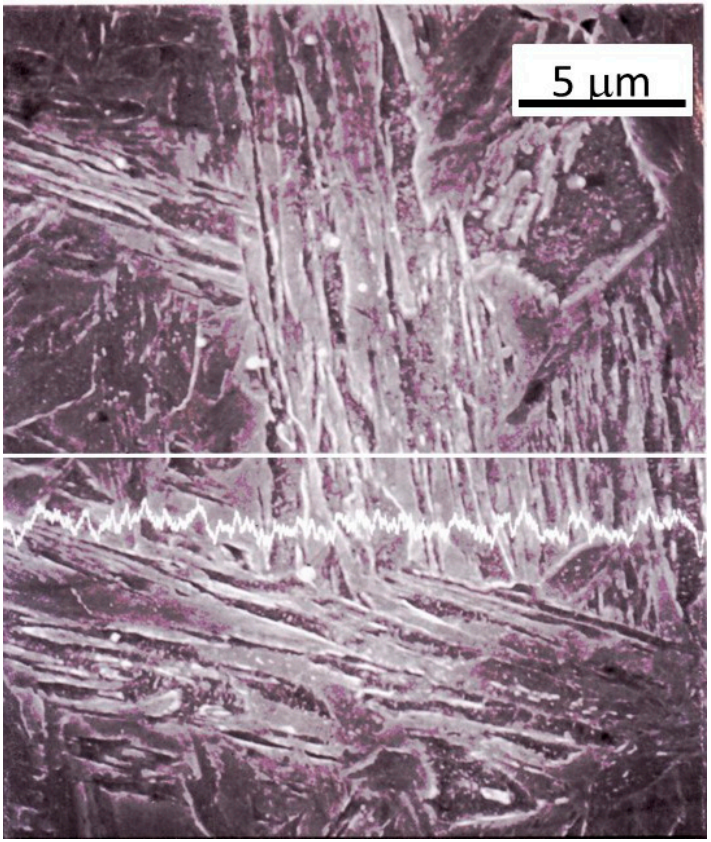

(a)

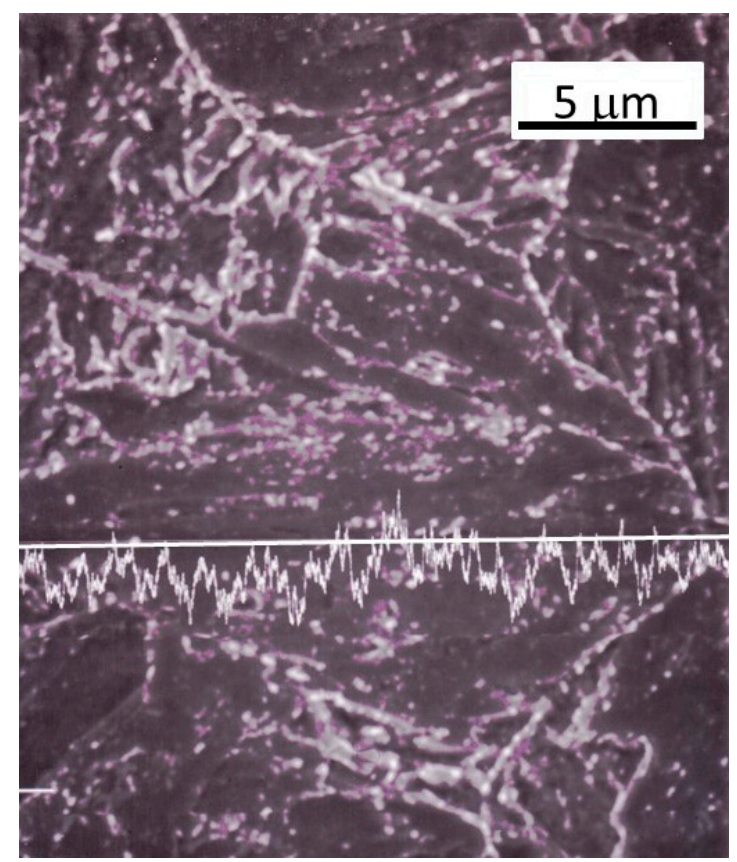

(b)

Figure 4. Structure of the steel as-quenched (a) and after the heat treatment at $700{ }^{\circ} \mathrm{C}$ for $10 \mathrm{~h}(\mathbf{b})$.

Table 3 reports the line breadths $\beta(2 \theta)$ of the most intense XRD reflections, namely $\{110\},\{200\}$ and $\{211\}$. In general, the $\beta(2 \theta)$ is progressively decreasing after the heat treatments due to the recovery of dislocation structures forming during the martensitic transformation consequent to the quenching from austenitic field.

Table 3. Line breadth $\beta(2 \theta)$ of the most intense X-ray diffraction (XRD) reflections.

\begin{tabular}{cccc}
\hline Heat Treatment & $\boldsymbol{\beta ( 2 \theta )} \mathbf{1 1 0}_{\mathbf{1 0}}$ & $\boldsymbol{\beta ( 2 \theta )} \mathbf{2 0 0}_{\mathbf{2 0}}$ & $\boldsymbol{\beta ( 2 \theta ) _ { \mathbf { 2 1 1 } }}$ \\
\hline As-quenched & 0.28 & 0.250 & 0.210 \\
$10 \mathrm{~h}$ at $700{ }^{\circ} \mathrm{C}$ & 0.21 & 0.200 & 0.150 \\
\hline
\end{tabular}

Figure 5 shows the fracture surfaces of the probes broken in Charpy tests in brittle and ductile field. The surfaces of the probes broken in brittle field exhibit the typical morphological features of quasi-cleavage fracture mode consisting of flat or slightly concave facets that arise from individual micro-cracks. They form independently and propagate through the material until coalesce. Tear ridges are observed in the zones, where the rupture of metal ligaments between different micro-cracks occurs leading to their coalescence (see the sketch in Figure 6). The fine steps inside each facet form when the propagating crack crosses groups of dislocations.

In the fracture surfaces of the samples heated at $700{ }^{\circ} \mathrm{C}$, several carbides are present and the zones, where the detachment of metal from carbides occurs, act as preferred nucleation sites for micro-cracks.

In the case of the ductile fractures, the dimples are the main characteristic. After heat treatment the

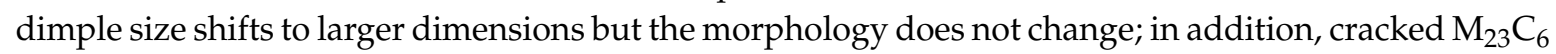
carbides (indicated by arrows in Figure 4) are observed inside the dimples. 


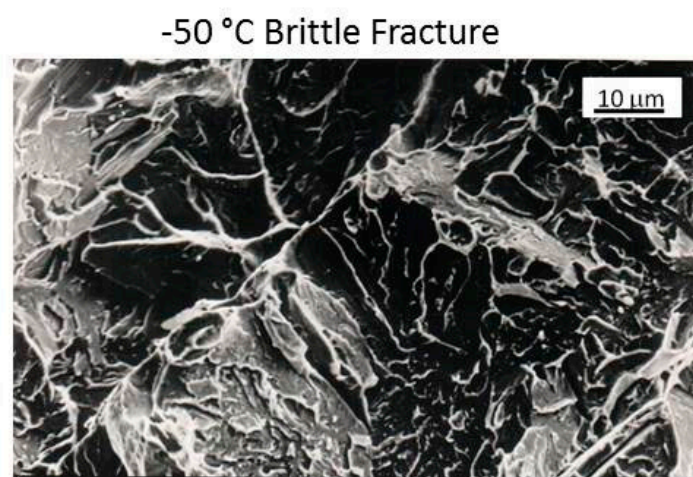

As-quenched

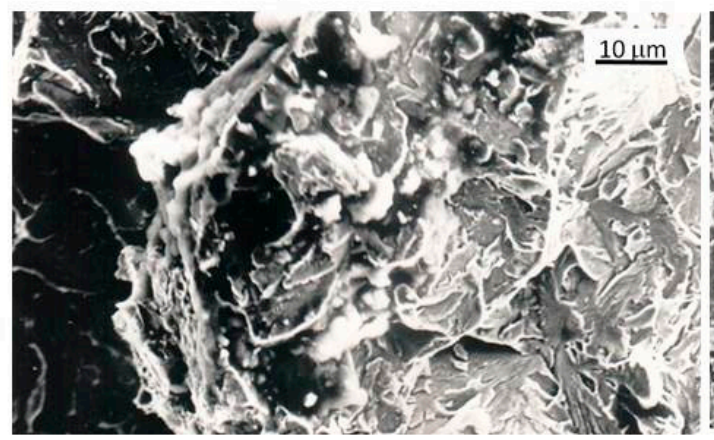

10 hours $/ 700^{\circ} \mathrm{C}$ $+100^{\circ} \mathrm{C}$ Ductile Fracture

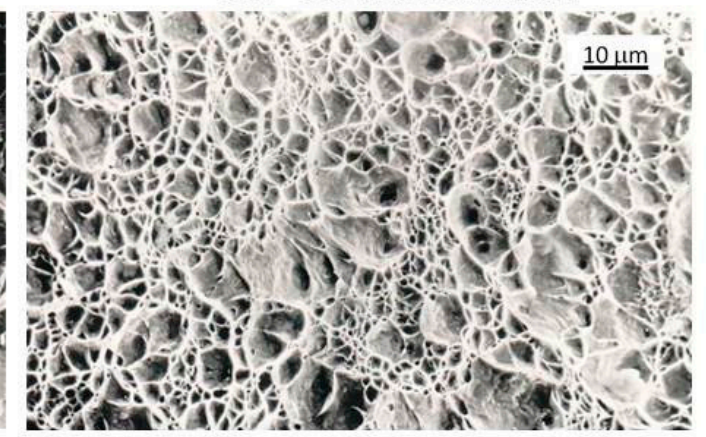

As-quenched

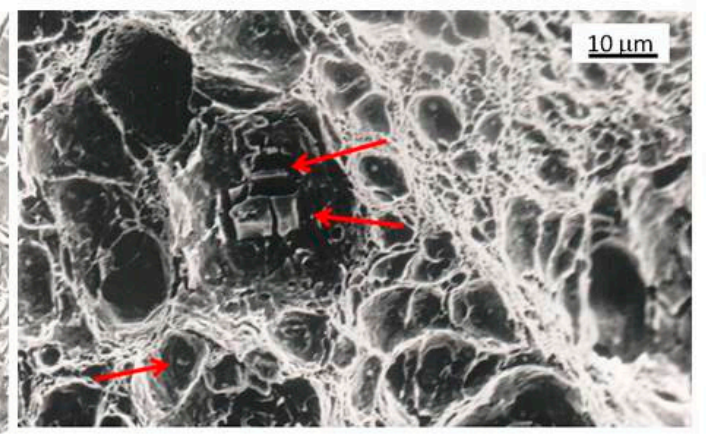

10 hours $/ 700{ }^{\circ} \mathrm{C}$

Figure 5. Fracture surfaces of the steel probes broken in Charpy tests in brittle $\left(-50{ }^{\circ} \mathrm{C}\right)$ and ductile field $\left(+100{ }^{\circ} \mathrm{C}\right)$.

\section{Metal ligaments}

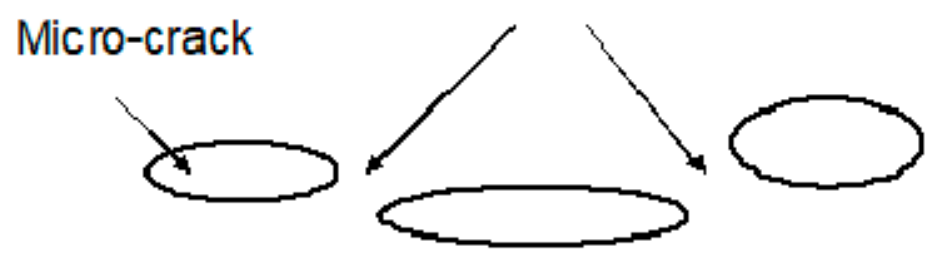

Tear ridges

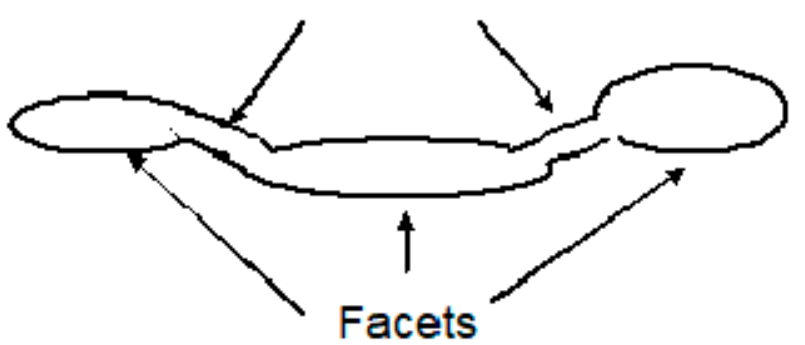

Figure 6. Schematic view of the coalescence process of micro-cracks in quasi-cleavage fracture mode.

The fracture surfaces of the two sets of samples have been investigated by XPS measurements. The spectra of whole Fe $2 \mathrm{p}$ and $\mathrm{Cr} 2 \mathrm{p}$ regions were acquired, but only the principal $2 \mathrm{p}_{3 / 2}$ peaks were taken into account for the qualitative and quantitative analysis in order to simplify the peak fitting procedure and to increase the accuracy of quantification. Figure 7 shows the Fe $2 \mathrm{p}_{3 / 2}$ and $\mathrm{Cr} 2 \mathrm{p}_{3 / 2}$ 
peaks of the XPS spectra measured on the fracture surfaces of as-quenched steel in both brittle $(a, b)$ and ductile fields (c,d).

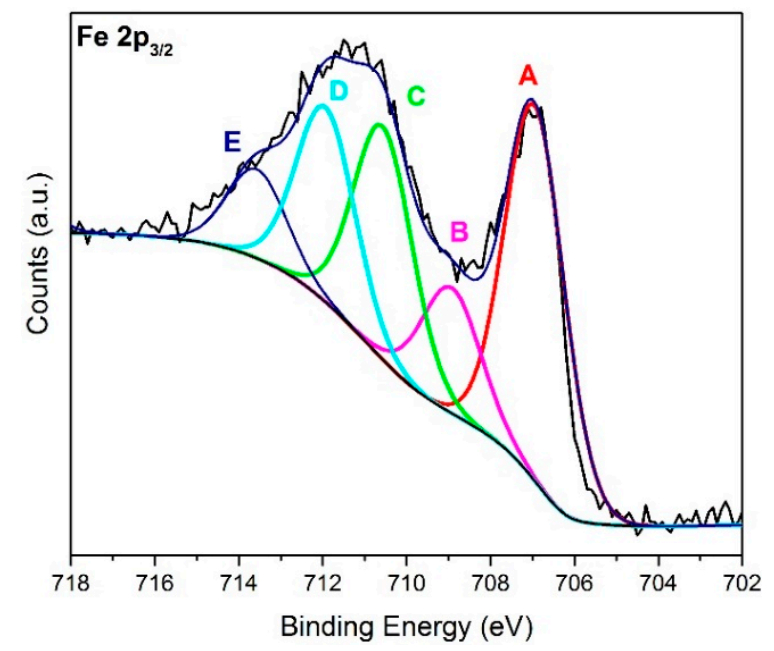

(a)

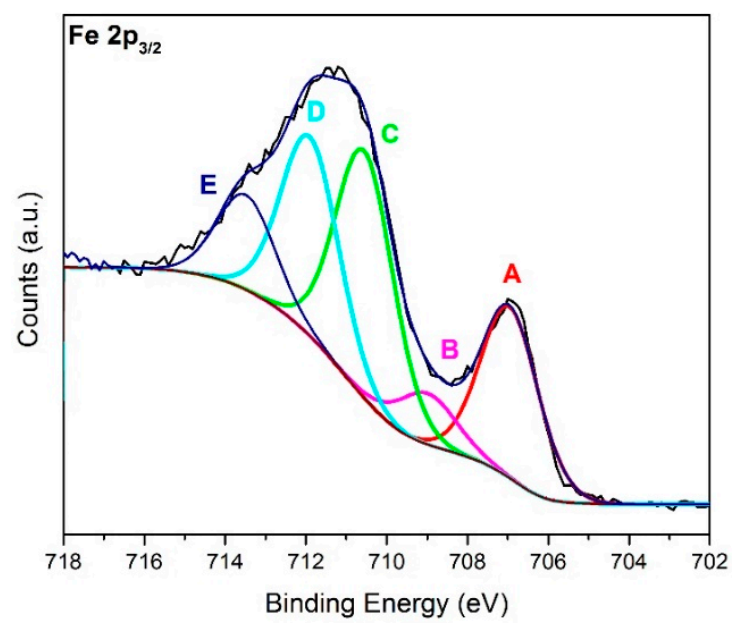

(c)

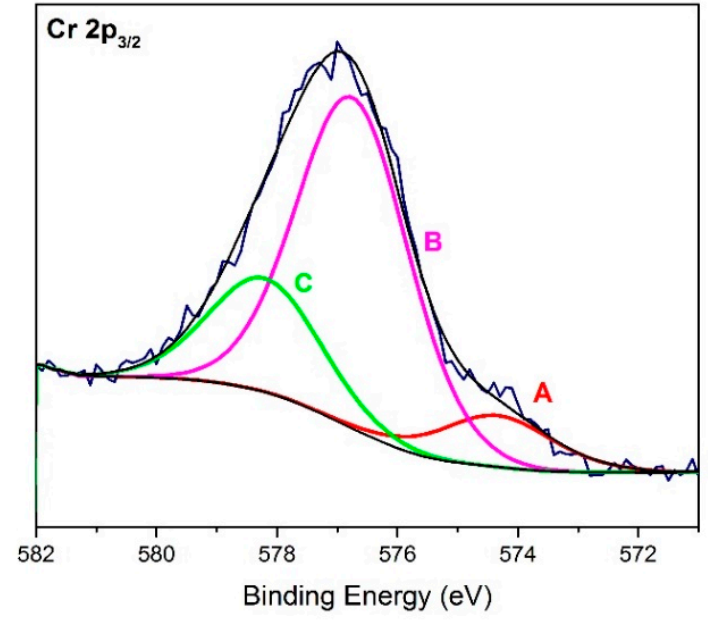

(b)

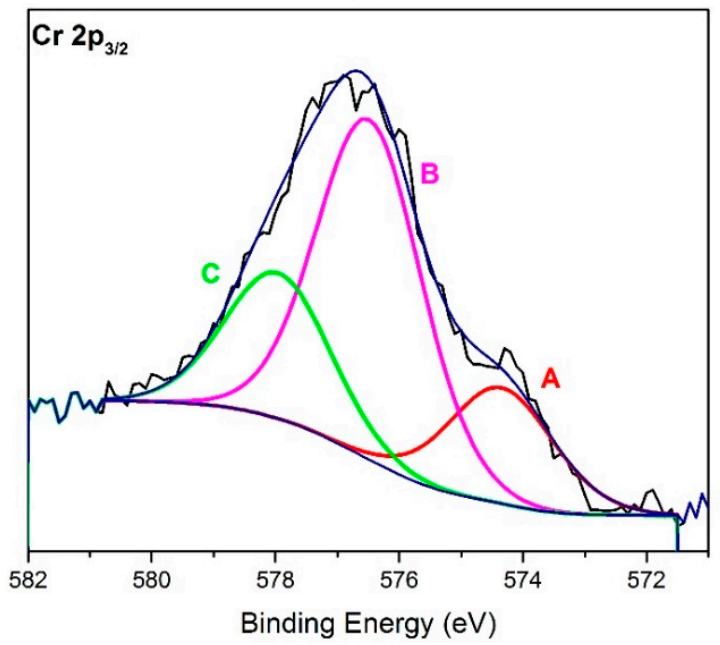

(d)

Figure 7. Peak fitting of $\mathrm{Fe} 2 \mathrm{p}_{3 / 2}$ and $\mathrm{Cr} 2 \mathrm{p}_{3 / 2}$ spectra of as-quenched samples broken in brittle $\left(-100{ }^{\circ} \mathrm{C}\right)$ field $(\mathbf{a}, \mathbf{b})$ and ductile $\left(+150^{\circ} \mathrm{C}\right)$ field $(\mathbf{c}, \mathbf{d})$.

The attribution of oxidation states for the components of $\mathrm{Cr}$ and Fe peaks was carried out after the "smart" background subtraction. The components of Fe $2 \mathrm{p}_{3 / 2}$ spectra (see Figure $7 \mathrm{a}, \mathrm{c}$ ) were the following: the first peak $\mathrm{A}$ at $\mathrm{BE}=707.0 \mathrm{eV}$ corresponding to metallic $\mathrm{Fe}^{0}$, peak $\mathrm{B}$ at $\mathrm{BE}=708.9 \mathrm{eV}$ corresponding to oxidized iron state $\mathrm{Fe}^{2+}$ and two other components $\mathrm{C}$ at $\mathrm{BE}=710.6 \mathrm{eV}$ and $\mathrm{D}$ at $\mathrm{BE}=711.9 \mathrm{eV}$ corresponding to iron states $\mathrm{Fe}^{3+}$ in oxide and hydroxide, respectively [33,34]. The last fitted component $\mathrm{E}$ at $\mathrm{BE}=713.6 \mathrm{eV}$ is a satellite peak, typical for the Fe oxides. Additionally, the $\mathrm{Cr}$ $2 \mathrm{p}_{3 / 2}$ spectra (see Figure $7 \mathrm{~b}, \mathrm{~d}$ ) had a metallic component $\mathrm{A}$ at $\mathrm{BE}=574.3 \mathrm{eV}$ and two components of $\mathrm{Cr}^{3+}$ states in oxide and hydroxide at $\mathrm{BE}=576.8 \mathrm{eV}(\mathrm{B})$ and $\mathrm{BE}=578.2 \mathrm{eV}(\mathrm{C})$, respectively [35]. All the components of $\mathrm{Fe} 2 \mathrm{p}_{3 / 2}$ and $\mathrm{Cr} 2 \mathrm{p}_{3 / 2}$ spectra, the quantitative weight percentage and respective chemical states are reported in Tables 4 and 5 . 
Table 4. Binding energy, X-ray photoelectron spectroscopy (XPS) quantification and chemical states of $\mathrm{Fe}$ and $\mathrm{Cr}$ of the samples broken in brittle field.

\begin{tabular}{|c|c|c|c|c|}
\hline Peak & $\mathrm{BE}(\mathrm{eV})$ & $\begin{array}{c}\text { As-Quenched } \\
\text { Wt. } \% \\
\left(\mathrm{~T}_{\text {charpy }}:-\mathbf{1 0 0}{ }^{\circ} \mathrm{C}\right)\end{array}$ & $\begin{array}{c}10 \mathrm{~h} \\
\mathrm{Wt} . \% \\
\left(\mathrm{~T}_{\text {charpy }}:-100{ }^{\circ} \mathrm{C}\right)\end{array}$ & State \\
\hline $\mathrm{Fe} 2 \mathrm{p}_{3 / 2}-\mathrm{A}$ & 707.0 & 24.0 & 31.7 & $\mathrm{Fe}^{0}$ \\
\hline $\mathrm{Fe} 2 \mathrm{p}_{3 / 2}-\mathrm{B}$ & 708.9 & 12.5 & 10.2 & $\mathrm{Fe}^{+2}$ \\
\hline $\mathrm{Fe} 2 \mathrm{p}_{3 / 2}-\mathrm{C}$ & 710.6 & 5.7 & 9.0 & $\mathrm{Fe}^{+3}$ \\
\hline $\mathrm{Fe} 2 \mathrm{p}_{3 / 2}-\mathrm{D}$ & 711.9 & 8.0 & 6.8 & $\mathrm{FeOOH}$ \\
\hline $\mathrm{Fe} 2 \mathrm{p}_{3 / 2}-\mathrm{E}$ & 713.6 & 14.9 & 4.3 & Satellite \\
\hline $\mathrm{Fe}_{\text {total }}$ & - & 65.1 & 62.0 & - \\
\hline $\mathrm{Cr} 2 \mathrm{p}_{3 / 2}-\mathrm{A}$ & 574.3 & 3.8 & 8.1 & $\mathrm{Cr}^{0}$ \\
\hline $\mathrm{Cr} 2 \mathrm{p}_{3 / 2}-\mathrm{B}$ & 576.8 & 23.1 & 22.1 & $\mathrm{Cr}$ (III) ox \\
\hline $\mathrm{Cr} 2 \mathrm{p}_{3 / 2}-\mathrm{C}$ & 578.2 & 8.0 & 7.8 & Cr(III) hydrox \\
\hline $\mathrm{Cr}_{\text {total }}$ & - & 34.9 & 38.0 & - \\
\hline
\end{tabular}

Table 5. Binding energy, XPS quantification, and chemical states of $\mathrm{Fe}$ and $\mathrm{Cr}$ of the samples broken in ductile field.

\begin{tabular}{|c|c|c|c|c|}
\hline Peak & $\mathrm{BE}(\mathrm{eV})$ & $\begin{array}{c}\text { As-Quenched } \\
\text { Wt. } \% \\
\left(\mathrm{~T}_{\text {charpy }}:+100^{\circ} \mathrm{C}\right)\end{array}$ & $\begin{array}{c}10 \mathrm{~h} \\
\mathrm{Wt} \% \\
\left(\mathrm{~T}_{\text {charpy }}:+100^{\circ} \mathrm{C}\right)\end{array}$ & State \\
\hline $\mathrm{Fe} 2 \mathrm{p}_{3 / 2}-\mathrm{A}$ & 707.0 & 18.1 & 10.8 & $\mathrm{Fe}^{0}$ \\
\hline $\mathrm{Fe} 2 \mathrm{p}_{3 / 2}-\mathrm{B}$ & 708.9 & 5.4 & 1.7 & $\mathrm{Fe}^{+2}$ \\
\hline $\mathrm{Fe} 2 \mathrm{p}_{3 / 2}-\mathrm{C}$ & 710.6 & 26.1 & 31.3 & $\mathrm{Fe}^{+3}$ \\
\hline $\mathrm{Fe} 2 \mathrm{p}_{3 / 2}-\mathrm{D}$ & 711.9 & 21.1 & 25.3 & $\mathrm{FeOOH}$ \\
\hline $\mathrm{Fe} 2 \mathrm{p}_{3 / 2}-\mathrm{E}$ & 713.6 & 10.0 & 11.0 & Satellite \\
\hline $\mathrm{Fe}_{\text {total }}$ & - & 80.0 & 80.1 & - \\
\hline $\mathrm{Cr} 2 \mathrm{p}_{3 / 2}-\mathrm{A}$ & 574.3 & 3.7 & 1.5 & $\mathrm{Cr}^{0}$ \\
\hline $\mathrm{Cr} 2 \mathrm{p}_{3 / 2}-\mathrm{B}$ & 576.8 & 10.9 & 16.7 & Cr(III) ox \\
\hline $\mathrm{Cr} 2 \mathrm{p}_{3 / 2}-\mathrm{C}$ & 578.2 & 5.7 & 1.7 & Cr(III) hydrox \\
\hline $\mathrm{Cr}_{\text {total }}$ & - & 20.0 & 19.9 & - \\
\hline
\end{tabular}

The same chemical states of $\mathrm{Fe}$ and $\mathrm{Cr}$ were present in all the fracture surfaces analysed, but the relative intensity of the metallic component with respect to oxide was changing. The intensity of metal and oxide components was very variable: these changes were found not only in different samples but also on different points of the same sample surface. Therefore, the overlayer of segregated $\mathrm{Cr}$ on the fracture surface layer is quite thin and not always homogeneously distributed. This result was visible from the comparison of the intensity between the $\mathrm{Fe} 2 \mathrm{p}_{3 / 2}$ components. In fact, in some specific surface areas, where the content of $\mathrm{Cr}$ was higher, the metallic Fe peak at $\mathrm{BE}=707.0 \mathrm{eV}$ had the same intensity of oxide component at $\mathrm{BE}=710.6 \mathrm{eV}$. In the cases where the amount of $\mathrm{Cr}$ was lower, the metallic $\mathrm{Fe}^{0}$ component was less intense than the oxidized one (see Figure $7 \mathrm{c}, \mathrm{d}$ ). Therefore, it could be assumed that metallic $\mathrm{Fe}^{0}$ on the surface is covered by a thin $\mathrm{Cr}$ film. Since the XPS measurements are extremely sensitive to the surface, the Cr overlayer must be quite thin (less than about $10 \mathrm{~nm}$ ) for the registration of Fe $2 p$ signal from metallic $\mathrm{Fe}^{0}$.

This hypothesis was also confirmed by the results of XPS depth profiles carried out on a surface area of $1.5 \times 1.5 \mathrm{~mm}^{2}$ with $\mathrm{Ar}^{+}$sputtering cycles of $30 \mathrm{~s}$ at ion energy of $2 \mathrm{keV}$. From these profiles (Figure 8) it was estimated that the $\mathrm{Cr}$-rich overlayer has a mean thickness of few nanometers in all the samples, independently on the test temperature or treatment time. Just a very short $\mathrm{Ar}^{+}$sputtering was enough for the complete removal of segregated Cr. In fact, after about 70-80 s of ion sputtering, the $\mathrm{Cr}$ signal is strongly reduced for any type of analysed fracture surfaces. From these results, it was possible to estimate the thickness of $\mathrm{Cr}$ overlayer. By using the calibrated sputtering rate of $0.17 \mathrm{~nm} / \mathrm{s}$, it was calculated that after $70-80 \mathrm{~s}$ of sputtering an overlayer of approximately $12-13 \mathrm{~nm}$ 
was removed from the surface. Unfortunately, this time-to-depth conversion is not very accurate, because it refers to ideal conditions, where the sample has a flat surface, whereas the steel fracture surfaces, especially those obtained in ductile field, were very irregular with the result of a shadowed sputtering effect, i.e., a non-uniform sputtering of the fracture surface [36]. For this reason, it is more correct to report the depth profiles in time scale, remembering that the thickness of Cr overlayer is over-estimated in the above calculation.

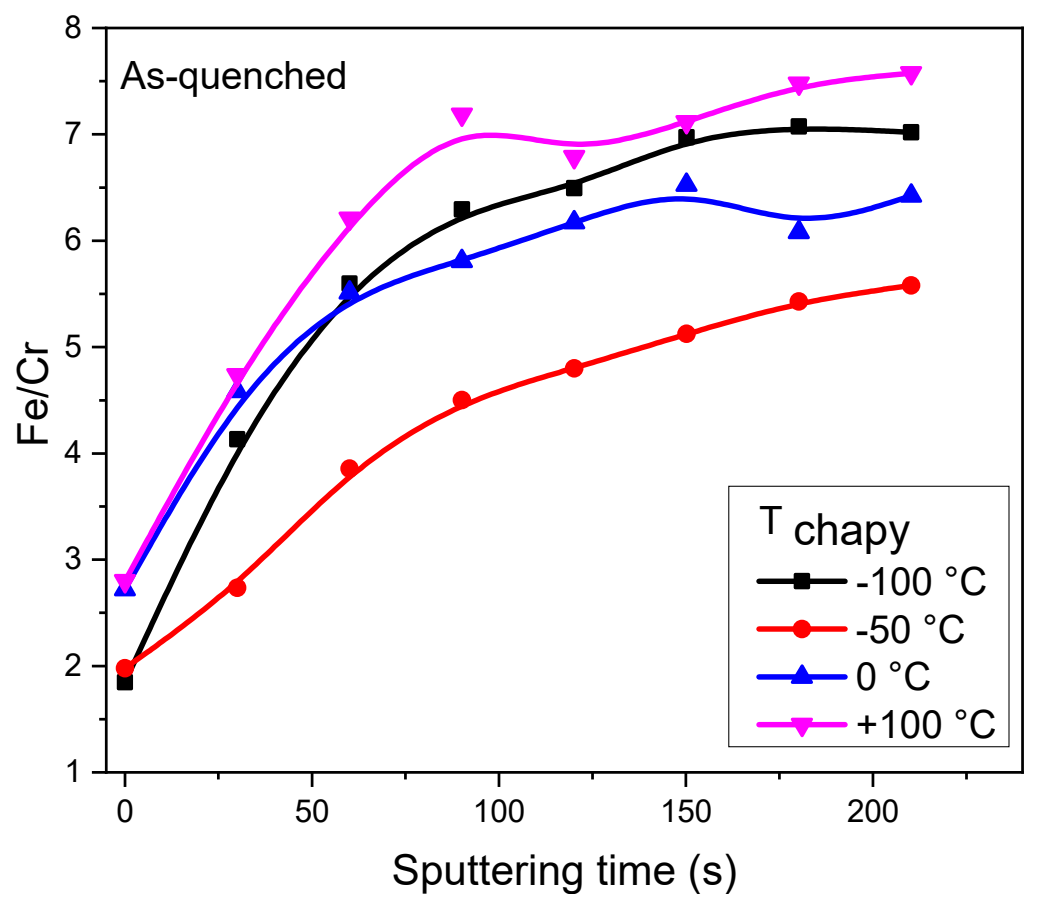

Figure 8. XPS depth profiles of $\mathrm{Fe} / \mathrm{Cr}$ ratio for as-quenched probes broken in Charpy tests at different temperatures.

To determine the $\mathrm{Cr}$ distribution, small-area (diameter of $300 \mu \mathrm{m}$ ) XPS line scans have been carried out across the fracture surfaces of probes broken in ductile $\left(+100{ }^{\circ} \mathrm{C}\right)$ and brittle $\left(-50\right.$ and $\left.-100{ }^{\circ} \mathrm{C}\right)$ fields. As shown in Figure 9a-c displaying the content (wt.\%) of Fe and $\mathrm{Cr}$ in different positions, the $\mathrm{Cr}$ distribution is much more homogeneous in the probes broken in ductile than in brittle field. It is evident that a strong Cr segregation is present at the centre of the brittle fracture surfaces (black line), of as-quenched and heat treated probes, whereas in the case of ductile fractures (red line) the $\mathrm{Cr}$ content is almost constant through the whole surface.

From the quantitative analysis of $\mathrm{Fe} 2 \mathrm{p}_{3 / 2}$ and $\mathrm{Cr} 2 \mathrm{p}_{3 / 2}$ peaks, it was observed an excess of $\mathrm{Cr}$ on the fracture surface of all the samples. This phenomenon is much stronger for the fractures obtained in brittle field, where about $40 \mathrm{wt}$.\% of Cr was observed, however $\mathrm{Cr}$ is always higher than $20 \mathrm{wt}$. \% also in ductile field, namely well above the value (10.5 wt.\%) of the steel nominal composition. These results are different from the $\mathrm{Cr}$ line scans obtained by EDS and reported in Figure 4, because the analysis depths of the two techniques are quite different. The maximum information depth of XPS is about $10 \mathrm{~nm}$ whereas in EDS it is in the micrometric scale and representative of the bulk value.

To verify whether the $\mathrm{Cr}$ enrichment evidenced by line scans of Figure $9 \mathrm{a}-\mathrm{c}$, is a specific feature of the fracture paths or, on the contrary, it is somehow connected to a macro-segregation phenomenon of the probes, the tests were also carried out under the same conditions on 6 different points of the flat surface of a probe cross-section after mechanical polishing (see Figure 9c). The average content of Cr was calculated to be of $10.6 \pm 0.3 \mathrm{wt}$.\%, corresponding to an experimental error less than $5 \%$ and, consequently, less than $10 \%$ for what concerns the Fe/Cr ratio. From the data in Figure $9 \mathrm{c}$, it is evident that there is no macro-segregation because the contents of Fe and $\mathrm{Cr}$ do not depend on the position, are nearly constant, and correspond to the nominal values of the steel composition. So, these results 
showed that the XPS data are extremely repeatable, consequently, the calculated values of the $\mathrm{Fe} / \mathrm{Cr}$ ratio, were in any case lower than the nominal ratio, after adding the experimental error. Therefore, the profiles in Figure 9a,b are specific of the fracture paths which advance through the material along the way of minor resistance, namely through the zones with higher $\mathrm{Cr}$ content.

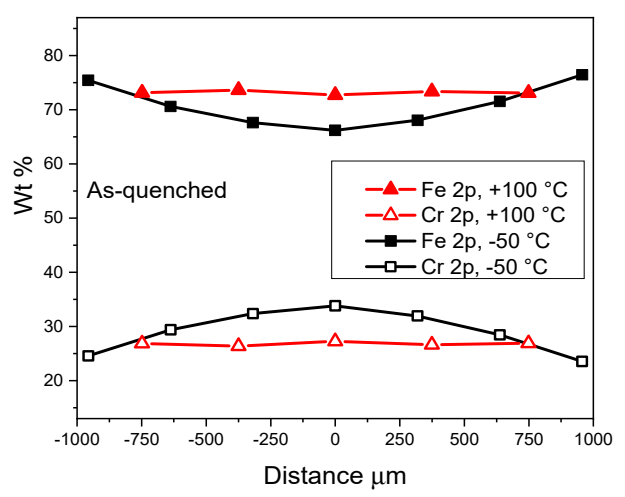

(a)

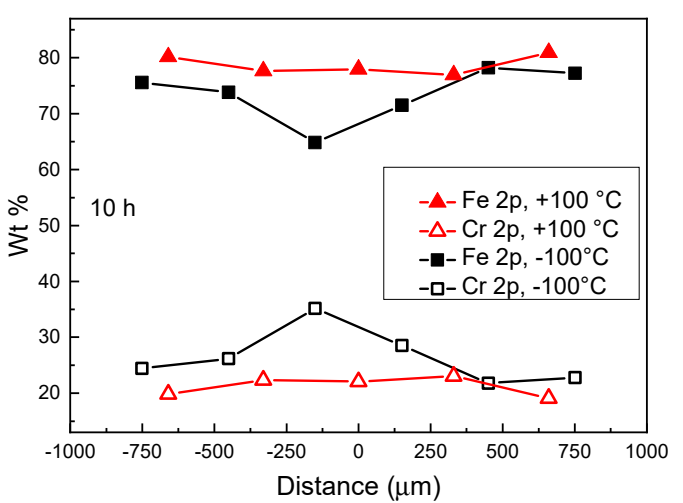

(b)

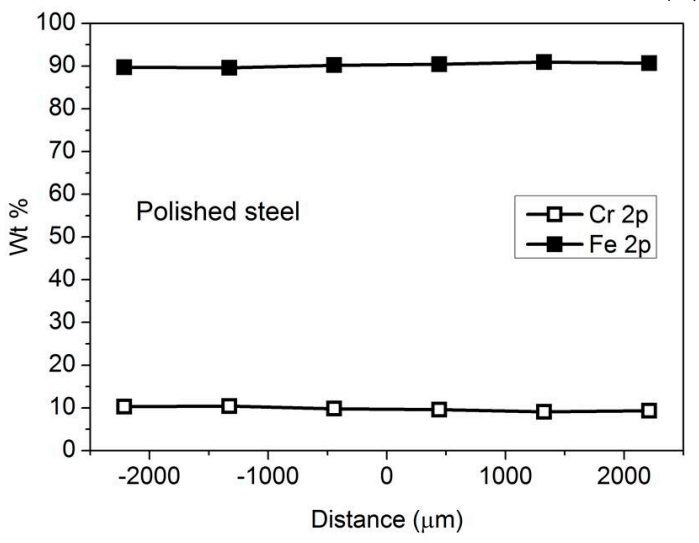

(c)

Figure 9. Small-area XPS line scans across the fracture surfaces of probes broken in brittle and ductile fields: (a) as-quenched and (b) treated at $700{ }^{\circ} \mathrm{C}$ for $10 \mathrm{~h}$. The indicated distance is taken from the fracture centre. For comparison, the scan of the cross-section of an as-quenched probe after mechanical polishing is shown in (c).

In order to deepen the $\mathrm{Cr}$ segregation phenomenon, the thermal gradients within the probe during cooling were determined via numerical simulation. For example, Figure 10 shows the profiles of temperature through a Charpy probe after a given time of cooling $(t=1.39 \mathrm{~min})$ as well as the corresponding distribution of martensite volume fraction. The inner part of the probe experiences a slower cooling than the surface thus the martensitic transformation starts at the surface and then moves to the inner part of the probe. In Figure 10b, the external part consists of martensite (red color), the inner part of austenite (blue color), while in the middle there is the presence of both the phases in different fractions depending on the distance from the surface. At room temperature the predicted microstructure is fully martensitic as in the real sample. 
a

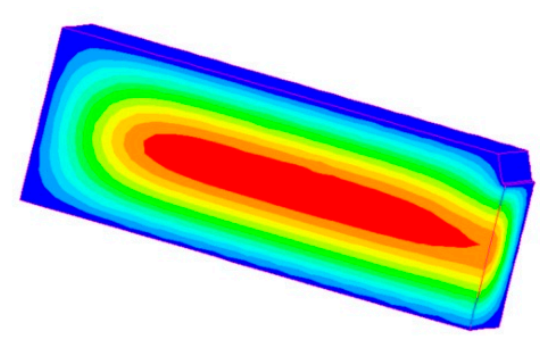

$\mathrm{b}$

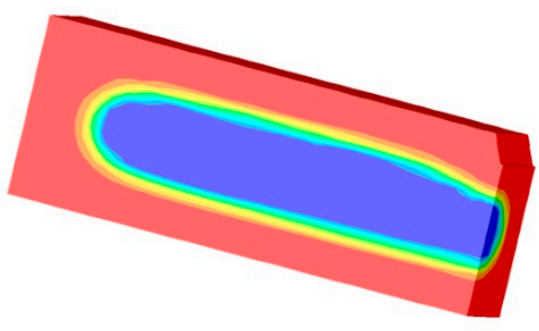

$\mathrm{T}\left({ }^{\circ} \mathrm{C}\right)$

$(\mathrm{t}=1.39 \mathrm{~min})$

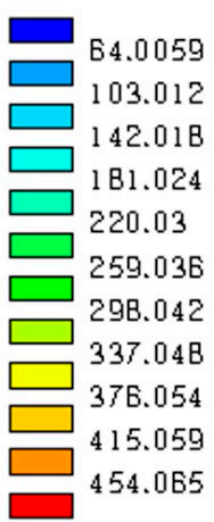

Mart. Proportion $(\mathrm{t}=1.39 \mathrm{~min})$

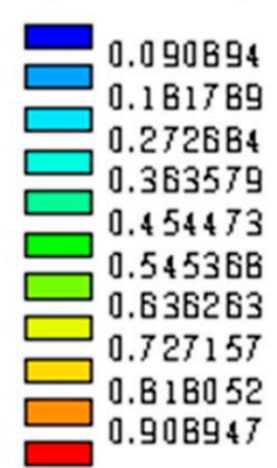

Figure 10. Calculated temperature (a) and martensite proportion (b) distribution at $1.39 \mathrm{~min}$ during cooling.

The thermal histories captured by two virtual probes located in the center (point A) and on the surface (point $\mathrm{B}$ ) of the cross section in correspondence of the notch are shown in Figure 11. The temperature inside the specimen (point A) during cooling is used to estimate the Cr diffusion distances close to the center of fracture surface.

In the conditions of present experiments, the random walk $(R W)$ of $\mathrm{C}$ and $\mathrm{Cr}$ atoms at the surface and in the internal part of Charpy probes was calculated vs. time on the basis of the trends reported in Figure 11. The calculation was made only for the austenitic phase because RW is negligible after the martensitic transformation at $375^{\circ} \mathrm{C}$. This permits also to neglect the $\mathrm{Cr}$ partitioning between austenite and martensite occurring in steels during isothermal treatments (e.g., see [37]).

$R W$ for the temperature $T$ and time $t$ is given by:

$$
R W=(6 D \mathfrak{t})^{1 / 2}
$$

where $D$ is the diffusion coefficient. The diffusion coefficients of $C$ and $C r$ in austenite were determined according to the following expressions:

$$
\begin{aligned}
& D_{C}=1.0 \times 10^{-5} \exp \left(\frac{-32400}{R T}\right)\left(\mathrm{m}^{2} \mathrm{~s}^{-1}\right) \\
& D_{C r}=1.08 \times 10^{3} \exp \left(\frac{-69700}{R T}\right)\left(\mathrm{m}^{2} \mathrm{~s}^{-1}\right)
\end{aligned}
$$


being $R$ the gas constant $\left(=1.987\left[\mathrm{cal} \mathrm{mol}^{-1} \mathrm{~K}^{-1}\right]\right)$. The RW values of $\mathrm{C}$ and $\mathrm{Cr}$ in points $\mathrm{A}$ and $\mathrm{B}$ plotted in Figure 12a,b were determined by integrating Equation (1) with time steps $d t$ of $0.06 \mathrm{~s}$.

Of course, $\mathrm{RW}$ of $\mathrm{C}$ is always higher than that of $\mathrm{Cr}$, however the most interesting result is the significant difference for both the elements between external and internal parts. In fact, the internal part of Charpy probes undergoes a slower cooling which allows a longer diffusion path of $\mathrm{C}$ and $\mathrm{Cr}$ atoms. Several experimental $[15,18-21]$ and simulation $[15,20]$ works give clear evidence of the clustering tendency in $\mathrm{Fe}-\mathrm{Cr}$ alloys which decreases as temperature increases, however MS measurements [5] and Monte Carlo simulations [24] showed that some $\mathrm{Cr}$ atoms aggregation occurs also in austenitic field, in particular C-Cr associates [22,26] act as preferred sites for the clustering of $\mathrm{Cr}$ atoms. It is evident that higher $\mathrm{RW}$ values involve favorable conditions for $\mathrm{Cr}$ atoms aggregation. As shown by Figure 9c, the formation of $\mathrm{Cr}$ enriched zones does not take place on a macroscopic scale otherwise it would be detected also on the polished surface of the probes but only on a microscopic scale.

In order to highlight the effects of $\mathrm{Cr}$ clustering on impact behaviour, the ratio $\mathrm{Fe} / \mathrm{Cr}$ of the mean values (wt.\%) measured on the fracture surface of all the samples has been calculated. From the nominal composition of steel, this ratio is 8.2 in the bulk material, whereas its value is noticeably lower for all the fracture surfaces, as shown by the plots in Figure 13.

The graphs of $\mathrm{Fe} / \mathrm{Cr}$ ratio vs. test temperature are somehow similar to the sigmoidal curves of absorbed energy displayed in Figure 2. For both the probe sets, the surfaces originated from brittle fractures exhibit a higher $\mathrm{Cr}$ content than the ductile ones, however the $\mathrm{Fe} / \mathrm{Cr}$ ratio is always rather far from the value corresponding to the chemical composition of the steel. The fracture surfaces are always enriched in $\mathrm{Cr}$ and this means that the microscopic $\mathrm{Cr}$ enriched zones represent a preferred path for cracks in both modes of fracture (brittle and ductile).

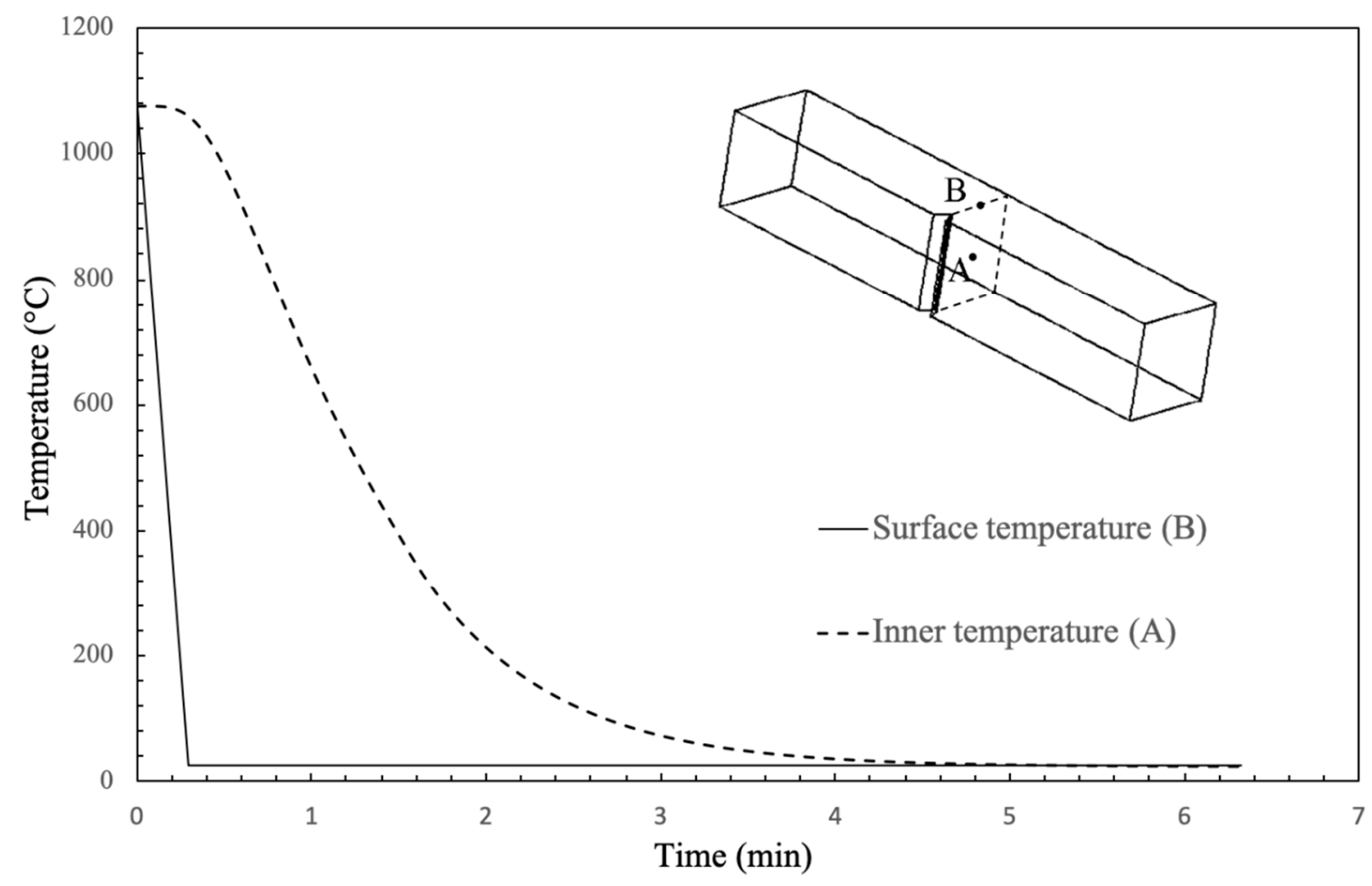

Figure 11. Calculated temperature histories at two points (A and B) of the Charpy specimen. 


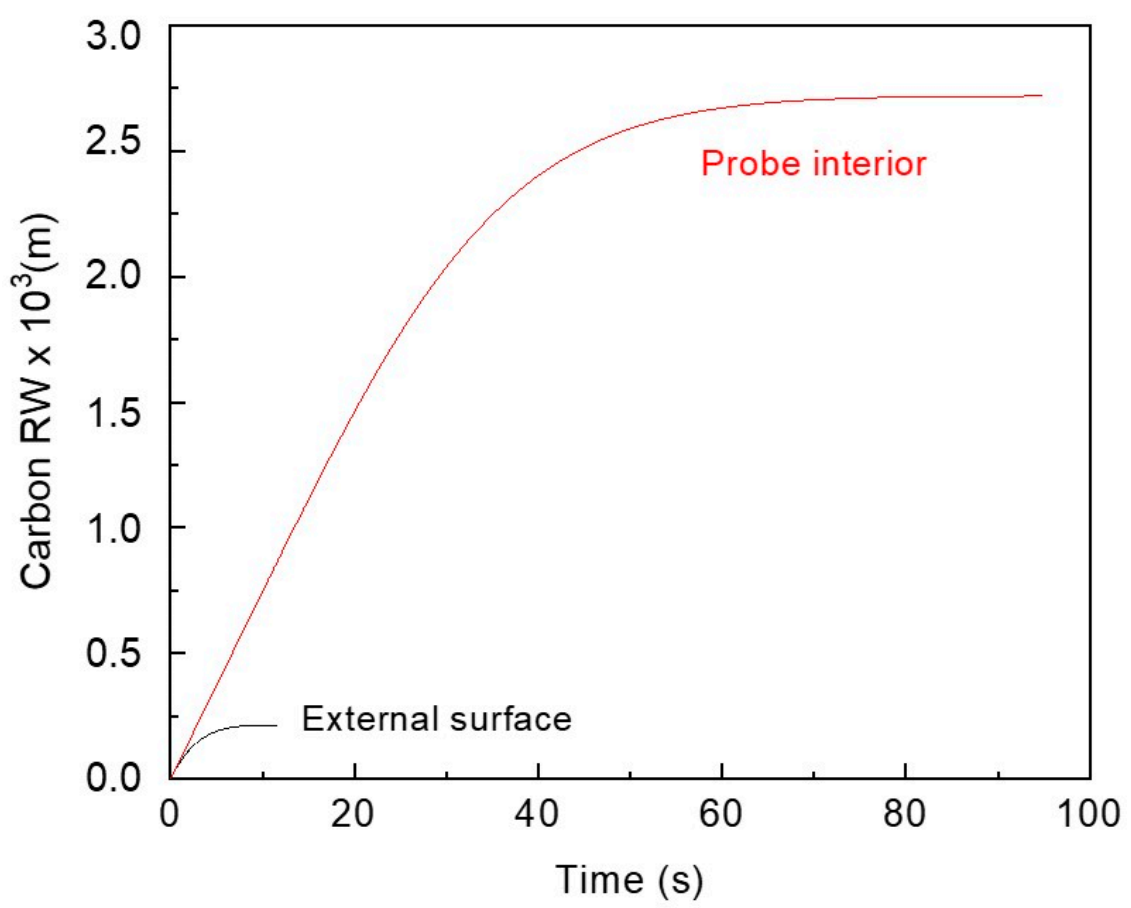

(a)

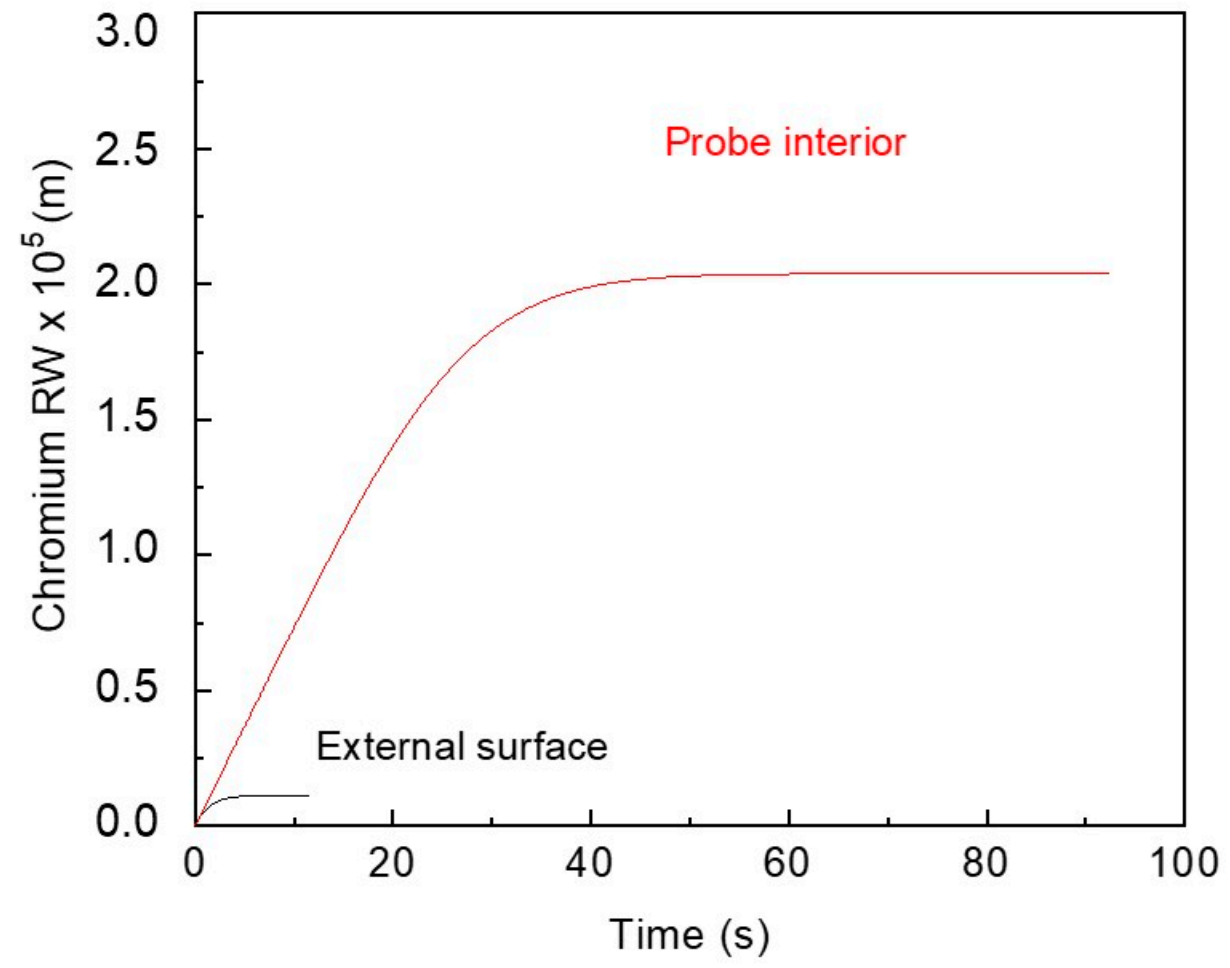

(b)

Figure 12. Random walk $(R W)$ of $\mathrm{C}(\mathbf{a})$ and $\mathrm{Cr}(\mathbf{b})$ atoms vs. time at the surface and in the internal part of Charpy probes calculated on the basis of the trends reported in Figure 11. 


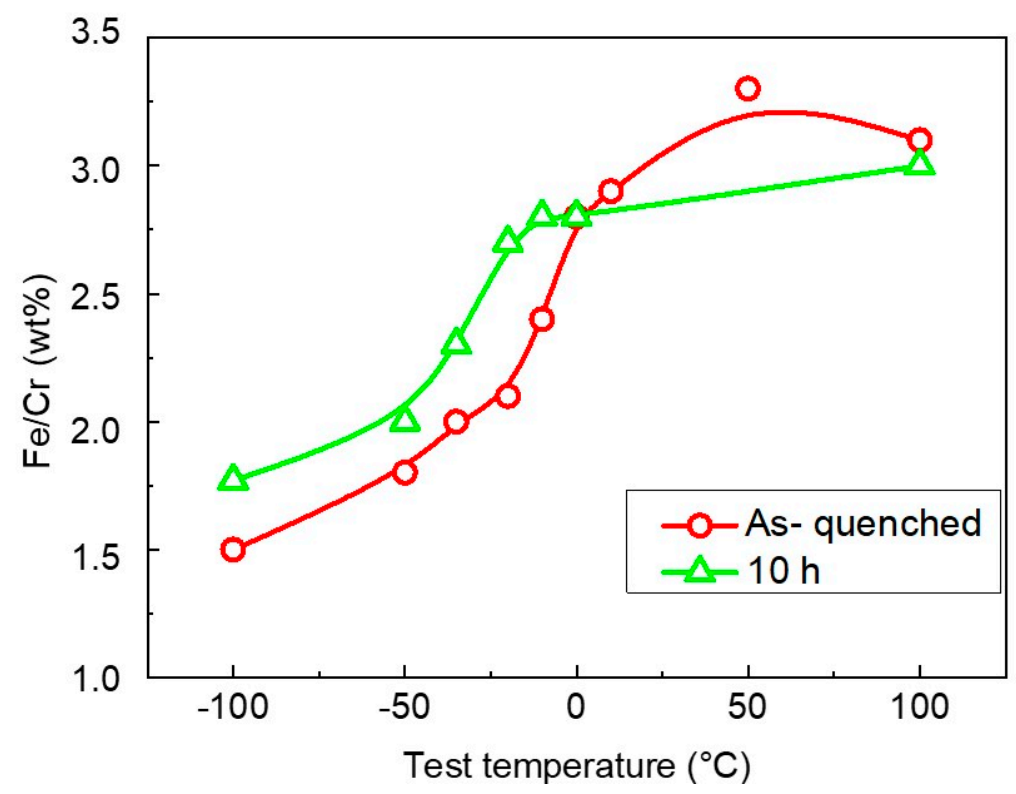

Figure 13. $\mathrm{Fe} / \mathrm{Cr}(\mathrm{wt} . \%)$ vs. test temperature of $\mathrm{Cr}$ martensitic steel in as-quenched condition and after the heat treatment for 10 at $700{ }^{\circ} \mathrm{C}$.

Line scans (Figure 9) and mean $\mathrm{Fe} / \mathrm{Cr}$ values (Figure 13) do not show relevant difference of $\mathrm{Cr}$ concentration in the surfaces resulting from ductile fractures of probes with and without heat treatment, while a little difference is observed in brittle field. In Fe-Cr alloys, the Mössbauer measurements [20] indicate a decreasing trend of short-range ordering $(\mathrm{SRO})$ parameter as temperature increases, however there is still a tendency to $\mathrm{Cr}$ clustering up to $700{ }^{\circ} \mathrm{C}$. Therefore, the heat treatment $\left(10 \mathrm{~h}\right.$ at $\left.700{ }^{\circ} \mathrm{C}\right)$ is not suitable to achieve the homogeneous $\mathrm{Cr}$ distribution in the steel matrix. A part of $\mathrm{Cr}$ atoms $(\sim 2.5 \mathrm{wt} . \%)$ [30] forms carbides (see Figure 3) but remaining $\mathrm{Cr}$ atoms are not uniformly distributed.

Previous works [10] on the same steel slowly cooled from austenitic field $\left(150^{\circ} \mathrm{C} / \mathrm{min}\right)$ showed that a mixed mode of fracture (quasi-cleavage plus inter-crystalline) occurs and EDS measurements evidenced $\mathrm{Cr}$ segregation in the areas of inter-crystalline fracture. This is in agreement with the theoretical work of Seah [38] and with experimental investigations on steels of similar composition [39] and more generally on $\mathrm{Fe}-\mathrm{Cr}$ alloys [40]. The embrittlement due to grain boundary segregation is the sum of effects due to bond-breaking, chemical interactions, and atomic size effects [41]. In the conditions of faster cooling rate $\left(3600^{\circ} \mathrm{C} / \mathrm{min}\right)$ examined here, the steel does not exhibit inter-crystalline fracture mode, however XPS results indicate that $\mathrm{Cr}$ segregation plays a role also in other modes of fracture including quasi-cleavage and ductile fractures.

No papers report specific XPS studies on the fracture surfaces of this material and, more in general, the literature is lacking in publications dealing with micro-chemical analyses on $\mathrm{Cr}$ martensitic steels. In the past, Auger electron spectroscopy (e.g., see [42-44]) has been used for studying high temperature embrittlement but the examined materials had a much higher $\mathrm{P}$ content than the steel examined here and the attention was focused on the role of $\mathrm{C}$ and $\mathrm{Cr}$ in determining the $\mathrm{P}$ content in grain boundaries. More recently, an investigation carried out by means of Scanning Auger Microscopy (SAM) on the fracture mode of turbine blades before and after service life shows that there is change in brittle fracture mode from intergranular to transgranular induced by a $\mathrm{Cr}$ redistribution from grain boundaries towards grain interior [44]. The mechanisms through which $\mathrm{Cr}$ segregation affects quasi-cleavage and ductile fracture modes are not yet completely clear and the topic deserves further investigation, therefore experiments are underway on sets of probes treated at increasing time at $700{ }^{\circ} \mathrm{C}$. 


\section{Conclusions}

XPS measurements have been carried out on the fracture surfaces of a $\mathrm{Cr}$ martensitic stainless steel in as-quenched condition and after a heat treatment of $10 \mathrm{~h}$ at $700{ }^{\circ} \mathrm{C}$. The results can be summarized as follows.

1. The mean $\mathrm{Fe} / \mathrm{Cr}$ ratio determined on the fracture surfaces of probes broken in both ductile and brittle fields is always significantly lower than the value corresponding to the steel nominal composition.

2. Small-area measurements revealed that the $\mathrm{Fe} / \mathrm{Cr}$ ratio is not constant across the surface and is lower in the inner part of the probe. FEM simulations show that this is due to a slower cooling rate in the inner part of Charpy probes that allows longer random walk of diffusing atoms.

3. The effect is observed in fractured probes but not in cross-sections after mechanical polishing, thus $\mathrm{Cr}$ segregation does not occur on macroscopic scale.

4. The Cr enrichment on the fracture surfaces indicates that the crack path preferentially follows the zones with $\mathrm{Cr}$ segregation.

5. Relevant differences of $\mathrm{Cr}$ concentration in fracture surfaces of probes with and without heat treatment were not observed.

Experiments are underway on sets of the probes treated for increasing time at $700{ }^{\circ} \mathrm{C}$ in order to understand the specific mechanisms relating $\mathrm{Cr}$ segregation and quasi-cleavage and ductile fractures.

Author Contributions: Conceptualization, E.B., A.F., P.F., S.K., A.M., R.M. and A.V.; Investigation, E.B., A.F., P.F., S.K., A.M., R.M. and A.V.; Validation, E.B., A.F., P.F., S.K., A.M., R.M. and A.V.; Writing, R.M., S.K. and E.B. All authors have read and agreed to the published version of the manuscript.

Funding: This work has been carried out within the framework of the EUROfusion Consortium and has received funding from the Euratom research and training programme 2014-2018 and 2019-2020 under Grant Agreement No. 633053. The views and opinions expressed herein do not necessarily reflect those of the European Commission.

Acknowledgments: The authors are grateful to Piero Plini and Benedetto Iacovone of Department of Industrial Engineering-University of Rome "Tor Vergata" for the assistance in sample preparation.

Conflicts of Interest: The authors declare no conflict of interest.

\section{References}

1. Mansur, L.K.; Coghlan, W.A. Mechanisms of helium interaction with radiation effects in metals and alloys: A review. J. Nucl. Mater. 1983, 119, 1-25. [CrossRef]

2. Harrelson, K.J.; Rou, S.H.; Wilcox, R.C. Impurity element effects on the toughness of 9Cr-1Mo steel. J. Nucl. Mater. 1986, 141-143, 508-512. [CrossRef]

3. Coppola, R.; Gondi, P.; Montanari, R.; Veniali, F. Structure evolution during heat treatments of $12 \% \mathrm{Cr}$ martensitic steel for NET. J. Nucl. Mater. 1988, 155-157, 616-619. [CrossRef]

4. Tavassoli, A.-A.F.; Diegele, E.; Lindau, R.; Luzginova, N.; Tanigawa, H. Current status and recent research achievements in ferritic/martensitic steels. J. Nucl. Mater. 2014, 455, 269-276. [CrossRef]

5. Gondi, P.; Montanari, R.; Sili, A. Effects of high temperature treatments on martensitic transformation in MANET steel. Z. Für Metallkd. 1994, 85, 664-669.

6. Albertini, G.; Ceretti, M.; Coppola, R.; Fiori, F.; Gondi, P.; Montanari, R. Small-angle neutron scattering of C-Cr elementary aggregates in a martensitic steel for fusion reactor technology. Physica B 1995, 213-214, 812-814. [CrossRef]

7. Brokmeier, H.G.; Coppola, R.; Montanari, R.; Rustichelli, F. Neutron diffraction study of the crystalline texture in a martensitic steel for fusion reactor technology. Physica B 1995, 213-214, 809-811. [CrossRef]

8. Brunelli, L.; Gondi, P.; Montanari, R.; Coppola, R. Internal strains after recovery of hardness in tempered martensitic steels for fusion reactors. J. Nucl. Mater. 1991, 179-181, 675. [CrossRef]

9. Coppola, R.; Lukas, P.; Montanari, R.; Rustichelli, F.; Vrana, M. X-ray and neutron line broadening measurements in a martensitic steel for fusion technology. Mater. Lett. 1995, 22, 17. [CrossRef] 
10. Gondi, P.; Montanari, R.; Sili, A.; Tata, M.E. Effects of thermal treatments on the ductile to brittle transition of MANET steel. J. Nucl. Mater. 1996, 233-237, 248-252. [CrossRef]

11. Hedströma, P.; Baghsheikhia, S.; Liu, P.; Odqvist, J. A phase-field and electron microscopy study of phase separation in Fe-Cr alloys. J. Mater. Sci. Eng. A 2012, 534, 552-556. [CrossRef]

12. Chen, D.; Kimura, A.; Han, W. Correlation of Fe/Cr phase decomposition process and age-hardening in Fe-15Cr ferritic alloys. J. Nucl. Mater. 2014, 455, 436-439. [CrossRef]

13. Li, H.; Xia, S.; Zhou, B.; Liu, W. C-Cr segregation at grain boundary before the carbide nucleation in Alloy 690. Mater. Charact. 2012, 66, 68-74. [CrossRef]

14. Zhou, X.; Yu, X.; Kaub, T.; Martens, R.L.; Thompson, G.B. Grain Boundary Specific Segregation in Nanocrystalline Fe (Cr). Nat. Sci. Rep. 2016, 6, 1-14. [CrossRef]

15. Kuronen, A.; Granroth, S.; Heinonen, M.H.; Perälä, R.E.; Kilpi, T.; Laukkanen, P.; Lång, J.; Dahl, J.; Punkkinen, M.P.J.; Kokko, K.; et al. Segregation, precipitation, and $\alpha-\alpha$ phase separation in Fe-Cr alloys. Phys. Rev. B 2015, 92, 1-16. [CrossRef]

16. Mirebeau, I.; Parette, G. Neutron Study of The Short Range Order Inversion in Fe1-x Crx. Phys. Rev. B. 2010, 82, 1-5. [CrossRef]

17. Dubiel, S.M.; Cieslak, J. Short-Range Order in Iron-Rich Fe-Cr Alloys as Revealed by Mössbauer Spectroscopy. Phys. Rev. B 2011, 83, 1-4. [CrossRef]

18. Dubiel, S.M.; Cieslak, J. Effect of Thermal Treatment on the Short-Range Order in Fe-Cr Alloys. Mater. Lett. 2013, 107, 86-89. [CrossRef]

19. Dubiel, S.M.; Cieslak, J.; Zukrowski, J. Distribution of Cr Atoms in The Surface Zone of Fe-Rich Fe-Cr Alloys Quenched into Various Media: Mössbauer Spectroscopic Study. Appl. Surf. Sci. 2015, 359, 526-532. [CrossRef]

20. Idczak, R.; Konieczny, R. Temperature dependence of the short-range order parameter for Fe0.90Cr0.10 and Fe0.88Cr0.12 alloys. Nukleonika 2015, 60, 35-38. [CrossRef]

21. Liu, M.; Aiello, A.; Xie, Y.; Sieradzki, K. The Effect of Short-Range Order on Passivation of Fe-Cr Alloys. J. Electrochem. Soc. 2018, 165, C830-C834. [CrossRef]

22. Gondi, P.; Montanari, R. On the Cr distribution in MANET steel. Phys. Status Solidi A 1992, 131, $465-480$. [CrossRef]

23. Gondi, P.; Montanari, R. $\mathrm{Q}^{-1}$ spectra connected with C under solute atom interaction. J. Alloys Compd. 1994, 211-212, 33. [CrossRef]

24. Coppola, R.; Gondi, P.; Montanari, R. Effects of C-Cr elementary aggregates on the properties of the MANET steel. J. Nucl. Mater. 1993, 206, 360-362. [CrossRef]

25. Gondi, P.; Montanari, R.; Sili, A.; Coppola, R. Solute Cr atom distribution and fracture behaviour of MANET steel. J. Nucl. Mater. 1994, 212-215, 564-568. [CrossRef]

26. Fava, A.; Montanari, R.; Varone, A. Mechanical spectroscopy investigation of point defects driven phenomena in a Cr martensitic steel. Metals 2018, 8, 870. [CrossRef]

27. Bolli, E.; Fava, A.; Kaciulis, S.; Mezzi, A.; Montanari, R.; Varone, A. XPS study of Cr segregation in a martensitic stainless steel. Surf. Interface Anal. 2020, 1-4. [CrossRef]

28. Xue, M.; Wang, S.; Wu, K.; Guo, J.; Guo, Q. Surface structural evolution in iron oxide thin films. Langmuir 2011, 27, 11-14. [CrossRef]

29. UNI EN ISO 148-1:2016 The International Organization for Standardization. Metallic Materials-Charpy Pendulum Impact Test (www.iso.org/obp/ui/\#iso:std:iso:148:-3:ed-3:v1:en); ISO: Geneva, Switzerland, 2016.

30. Koistinen, D.P.; Marburger, R.E. A general equation prescribing extent of austenite-martensite transformation in pure iron-carbon alloys and carbon steels. Acta Metall. 1959, 7, 59-68. [CrossRef]

31. Ferro, P.; Bonollo, F.; Berto, F.; Montanari, R. Numerical modelling of residual stress redistribution induced by TIG-dressing. Frattura Integrità Strutt. 2019, 47, 221-230. [CrossRef]

32. Jung, P.; Klein, H. Segregation in DIN 1.4914 martensitic stainless steel under proton irradiation. J. Nucl. Mater. 1991, 182, 1-5. [CrossRef]

33. Lin, T.-C.; Seshadri, G.; Kelber, J.A. A consistent method for quantitative XPS peak analysis of thin oxide films on clean polycrystalline iron surfaces. Appl. Surf. Sci. 1997, 119, 83-92. [CrossRef]

34. Biesinger, M.C.; Payne, B.P.; Grosvenor, A.P.; Lau, L.W.M.; Gerson, A.R.; Smart, R.S.C. Resolving surface chemical states in XPS analysis of first row transition metals, oxides and hydroxides: $\mathrm{Cr}, \mathrm{Mn}, \mathrm{Fe}, \mathrm{Co}$ and $\mathrm{Ni}$. Appl. Surf. Sci. 2011, 257, 2717-2730. [CrossRef] 
35. Hofmann, S. Depth Profiling in AES and XPS. In Practical Surface Analysis; Briggs, D., Seah, M.P.J., Eds.; Wiley and Sons: Chichester, UK, 1990; pp. 143-199.

36. De Sanctis, M.; Valentini, R.; Lovicu, G.F.; Dimatteo, A.; Migliaccio, U.; Montanari, R.; Pietrangeli, E. Microstructural features affecting tempering behaviour of $16 \mathrm{Cr}-5 \mathrm{Ni}$ supermartensitic steel. Metall. Mater. Trans. A 2015, 46, 1878-1887. [CrossRef]

37. Seah, M.P. Adsorption-induced interface decohesion. Acta Metall. 1980, 28, 955-962. [CrossRef]

38. Schäublin, R.; Spätig, P.; Victoria, M. Chemical segregation behavior of the low activation ferritic/martensitic steel F82H. J. Nucl. Mater. 1998, 258-263, 1350-1355. [CrossRef]

39. Saraf, L.V.; Lea, A.S.; Wang, C.M.; Dohnalkova, A.; Arey, B.W. Chromium Segregation at the Grain Boundaries in Ni-Fe-Cr Alloys. Microsc. Microanal. 2010, 16, 690-691. [CrossRef]

40. Gibson, M.A.; Schuh, C.A. A survey of ab-initio calculations shows that segregation-induced grain boundary embrittlement is predicted by bond-breaking arguments. Scr. Mater. 2016, 113, 55-58. [CrossRef]

41. Lemble, P.H.; Pineau, A.; Castagne, J.L.; Dumoulin, P. Temper embrittlement in 12\%Cr martensitic steel. Met. Sci. 1979, 13, 496-502. [CrossRef]

42. Prabhu Gaunkar, G.V.; Huntz, A.M.; Lacombe, P. Role of carbon in embrittlement phenomena of tempered martensitic 12\%-0.15\% C steel. Met. Sci. 1980, 14, 241-252. [CrossRef]

43. Lei, T.C.; Sun, J.; Tang, C.H.; Lei, M. Precipitation-segregation mechanism for high temperature temper embrittlement of steels revealed by Auger electron spectroscopy and internal friction measurements. Mater. Sci. Technol. 1990, 6, 124-133. [CrossRef]

44. Saidi, D.; Zaid, B.; Souami, N.; Negache, M.; Si Ahmed, A. Microstructure and fracture mode of a martensitic stainless steel steam turbine blade characterized via scanning auger microscopy and potentiodynamic polarization. In Proceedings of the International Symposium on Advanced Materials (ISAM 2013), Islamabad, Pakistan, 23-27 September 2013; pp. 1-9.

(C) 2020 by the authors. Licensee MDPI, Basel, Switzerland. This article is an open access article distributed under the terms and conditions of the Creative Commons Attribution (CC BY) license (http://creativecommons.org/licenses/by/4.0/). 